\title{
A note on some epiphytic plants for their repellent activities against Tribolium castaneum adults
}

\author{
S.B. Chhabi ${ }^{1}$, M. Asaduzzaman ${ }^{1}$, S. Das $^{1}$ and N. Islam ${ }^{2}$ \\ ${ }^{1}$ Department of Genetic Engineering and Biotechnology, University of Rajshahi, Rajshahi-6205; \\ Bangladesh; ${ }^{2}$ Department of Zoology, University of Rajshahi, Rajshahi-6205, Bangladesh
}

Repellents, fumigants, feeding deterrents, growth inhibitors and insecticides of natural origin are rational alternatives to synthetic insecticides. Some plants draw a special attention for their low lethal and other environment-friendly activities (Talukder \& Howse, 1995). Epiphytes or air plants that do not normally root in the soil but grow upon another living plant, draw attention as a source of bioactive potentials. Use of these plants in the traditional system of folk medicine is well known (Mallavadhani et al., 2003). Epiphytes of Bangladesh remain untouched from investigation for their bioactive potentials. In this proposition six epiphytic plants viz. Dendrophthoe falcate (L.f.) Ettingsh. Cuscuta reflexa Roxb., Drynaria roxburghii (Bory) J. Sm., Ficus lacor Buch.-Ham., Vanda roxburghii $\mathrm{R}$. Br. and Loranthus longiflorus Desr., were taken into consideration for evaluating their repellent activities.

Mallayadhani et al. (2006) mentioned that $D$. falcata has estrogen receptor binding activity. In the Ayurvedic medicine C. reflexa is said to be useful in diseases of eye and heart (Chopra et al., 1956). F. lacor stem bark is used in gastric and ulcer (Bajracharya et al., 1978; Bhattarai et al., 2000; Pandey, 2001; Rai et al., 2004). Its milky latex of stem is used in typhoid and heavy fever, dysentery and boils (Oli, 2001). Decoction of buds is considered for ulcer and leucorrhoea (Chopra et al. 1956), gargle in salivation (Malla, 1994), boils, pimples and blisters (Manandhar, 1985). Dried buds of $F$. lacor are used to treat harsa (Nakarmi, 2001) and seeds are tonic in nature and used in treatment of stomach disorder (Bhatt, 1977). Loranthus species in semiparasitic plants are known to produce variety of bioactive compounds; i.e., sesquiterpene lactones for the treatment of schizophrenia (Okuda et al., 1987) and (+)catechin, 3,4- dimethoxycinnamyl alcohol and 3,4,5-trimethoxycinnamyl alcohols for the antimicrobial and antifungal properties (Sadik et al., 2003). Many other chemical components such as triterpenoids from L. grewinkii (Rahman et al., 1973), and L. falcatus (Anjaneyulu et al., 1977), flavonoids from the leaves of $L$. kaoi (Lin \& Lin, 1999) and from L. europaeus (Harvala et al.,
1984), a cytotoxin from L. parasiticus (Zhou et al., 1993), and phenolics from L. longiflorus (Indrani et al., 1985) have been reported so far. Other biological activities have also been reported, such as, antihypertensive effect (Obatomi et al., 1996), antiviral activity of $L$. parasiticus (Kusumoto et al., 1992), anti-diabetic properties of $L$. bengwensis (Obatomi et al., 1994). V. roxburghii contains heptacosane and octacosanol that show antiinflammatory activity (Okuda et al., 1987). No information was available on the biological activity of D. roxburghii. However, previous workers investigated these plants giving emphasis mostly on the chemical constituents and their medicinal profile but a very few were given touch on agricultural openings, and information on their various biological activities is still scanty. Here repellent activity tests of these plants have been attempted to evaluate their efficacy as environment-friendly pest control agents.

Epiphytic plants $D$. falcata of family Loranthaceae, C. reflexa of family Convolvulaceae, D. roxburghii of family Polypodiaceae, $F$. lacor of family Moraceae, $V$. roxburghii of family Orchidaceae and $L$. longiflorus of family Loranthaceae were collected from Rajshahi and Chapai Nawabganj Districts and were identified at the Bangladesh National Herbarium, Mirpur, Dhaka, Bangladesh. The materials were dried in a well-ventilated room under shade from 3 to 7 days and powdered in a hand grinder. The powdered materials were weighed and placed in separate conical flasks to add chloroform $(30 \mathrm{~g} \times 100 \mathrm{ml} \times 3$ times $)$ and filtration was done at $24 \mathrm{~h}$ interval. The output extracts were transferred to glass vials and preserved in a refrigerator at $4^{\circ} \mathrm{C}$ until used.

The insect used in this study was the red flour beetle, Tribolium castaneum (Herbst) (Coleoptera: Tenebrionidae). The stock culture was maintained in the laboratory at $30 \pm 0.5^{\circ} \mathrm{C}$. The whole-wheat flour was sterilized at $60^{\circ} \mathrm{C}$ for 36 hours in an oven. A standard mixture of whole-wheat flour and powdered dry yeast in a ratio of 19:1 (ZyromskaRudzka, 1966) was used as food medium. In regular intervals the eggs were collected by sieving the food medium by two sieves of 500 and 
250 mesh sizes for separating the adults and eggs, respectively following the methods of Khan and Selman (1981). A huge number of beetles were thus reared to get a regular supply of the newly formed adults.

The repellency test used was adopted from the method of McDonald et al. (1970) with some modifications by Talukder and Howse (1993, 1994). Half filter paper discs (Whatman No. 40, 9 $\mathrm{cm}$ diameter) were prepared and five doses (4.938, 2.469, 1.235, 0.617 and $0.309 \mathrm{\mu g} \mathrm{cm}^{-2}$ ) of all the $\mathrm{CHCl}_{3}$ extracts were applied separately onto each of the half-disc and allowed to dry out in the air for $10 \mathrm{~min}$. Each treated half-disc was then attached lengthwise, edge-to-edge, to a control half-disc with adhesive tape and placed in a Petri dish $(9 \mathrm{~cm}$ dia.). Ten adult insects were released in the middle of each filter paper circle each dose was tested three times. Insects that settled on each half of the filter paper disc were counted after $1 \mathrm{~h}$ and then at hourly intervals for $5 \mathrm{~h}$. The average of the counts was converted to percent repellency $(P R): P R=2(C-50)$, where $C$ is the percentage of insects on the untreated half of the disc. Positive values expressed repellency and negative values attractant activity. The data were finally subjected to arcsin transformation for the calculation of ANOVA and interpretation for the repellency was made by the $F$ values through 5,1 and $0.1 \%$ levels of significance.

The repellent activity results of the six epiphytes against $T$. castaneum were promising since five test materials among six found strongly effective (Table 1 and 2). Except the $D$. falcata extract C. reflexa, D. roxburghii, F. lacor, V. roxburghii and $L$. longiflorus extracts were found potent and their repellency due to differences between doses were highly significant $(\mathrm{P}<0.001)$, however, differences between time intervals for all the epiphytic extracts were statistically non-significant $(P>0.05)$. According to the intensity of repellency the extracts could be arranged in a descending order as: $V$. roxburghii $>$ L. longiflorus $>D$. roxburghii $>$ C. reflexa> F. lacor. These findings are supported by some previous workers, however none of the biological activities reported was on repellency by any of the six test plants. $D$. falcata has estrogen receptor binding activity (Mallayadhani et al., 2006) that on the other hand offer male antifertility agents and properties for the inhibition of spermatogenesis. Methanol extracts of $C$. reflexa stem showed a broad spectrum of antibacterial activity against Pseudomonas aeruginosa, Escherichia coli, Bacillus subtilis and Bacillus licheniformis, and fungi namely Aspergillus niger and Trichoderma reesei (Aggarwal \& Dutt, 1935). The extract of $F$. lacor exhibited inhibition in adiorespirometry assay using ACTEC system with rifampin as positive control and the allied species F. retusa L., F. lacor Ham. and F. cunia Ham. ex Roxb. found potent for curing leprosy; F. religiosa L., F. rumphii $\mathrm{BI}$. and $F$. heterophylla $\mathrm{L}$. for asthma; and all these materials are used in the folklore medicine of Puerto Rico (Kirtikar \& Basu, 1935). The stembark of $F$. lacor contains B-sitosterol, a-D-glucose and meso-inositol, the leaves contain petunidin di-glycoside and quercentin 3-galactoside and the fruits contain cyanidin rhamnoglycoside and polysaccharides, which have been found bioactive (Kirtikar \& Basu, 1935). Loranthus species are known to produce variety of bioactive compounds (Okuda et al., 1987) and the antimicrobial and antifungal properties (Sadik et al., 2003).

Table 1. Percent repellency of $T$. castaneum adults by chloroform extracts of six epiphytic plants

\begin{tabular}{|c|c|c|c|c|c|c|}
\hline \multirow[t]{2}{*}{ Plant } & \multirow{2}{*}{$\begin{array}{c}\text { Dose } \\
\left(\mu \mathrm{g} \mathrm{cm}^{-2}\right)\end{array}$} & \multicolumn{5}{|c|}{ Percent repulsion (PR) } \\
\hline & & $1 \mathrm{~h}$ & $2 \mathrm{~h}$ & $3 \mathrm{~h}$ & $4 \mathrm{~h}$ & $5 \mathrm{~h}$ \\
\hline \multirow{5}{*}{ D. falcata } & 4.938 & 60 & 0 & -93.4 & -93.4 & -73.4 \\
\hline & 2.469 & -26.6 & -33.4 & -33.4 & -13.4 & 31.05 \\
\hline & 1.235 & -46.6 & -26.6 & -40 & -33.4 & -33.4 \\
\hline & 0.617 & 20 & 20 & 13.4 & 33.4 & 26.6 \\
\hline & 0.309 & -6.6 & -13.4 & -20 & -13.4 & -20 \\
\hline \multirow{5}{*}{ C. reflexa } & 4.938 & 80 & 73.4 & 93.4 & 100 & 100 \\
\hline & 2.469 & 100 & 93.4 & 93.4 & 93.4 & 93.4 \\
\hline & 1.235 & 73.4 & 93.4 & 86.6 & 80 & 86.6 \\
\hline & 0.617 & 6.6 & -20 & 33.4 & 20 & 13.4 \\
\hline & 0.309 & 80 & 86.6 & 66.6 & 53.4 & 80 \\
\hline \multirow{5}{*}{$\begin{array}{c}D . \\
\text { roxburghii }\end{array}$} & 4.938 & 100 & 86.6 & 73.4 & 100 & 100 \\
\hline & 2.469 & 66.6 & 26.6 & 53.4 & 46.6 & 40 \\
\hline & 1.235 & 93.4 & 100 & 100 & 93.4 & 93.4 \\
\hline & 0.617 & 33.4 & 26.6 & 33.4 & 33.4 & 33.4 \\
\hline & 0.309 & 66.6 & 26.6 & 33.4 & 40 & 26.6 \\
\hline \multirow{5}{*}{ F. lacor } & 4.938 & 33.4 & 46.6 & 46.6 & 40 & 33.4 \\
\hline & 2.469 & 53.4 & 66.6 & 46.6 & 53.4 & 60 \\
\hline & 1.235 & 46.6 & 60 & 73.4 & 53.4 & 66.6 \\
\hline & 0.617 & 13.4 & 13.4 & 26.6 & 6.6 & -6.6 \\
\hline & 0.309 & 73.4 & 60 & 80 & 93.4 & 53.4 \\
\hline \multirow{5}{*}{$\begin{array}{c}\text { V. } \\
\text { roxburghii }\end{array}$} & 4.938 & -6.6 & -46.6 & 0 & 6.6 & -6.6 \\
\hline & 2.469 & 93.4 & 100 & 100 & 100 & 100 \\
\hline & 1.235 & 40 & 53.4 & 40 & 40 & 53.4 \\
\hline & 0.617 & 6.6 & 0 & 6.6 & 0 & -13.4 \\
\hline & 0.309 & 26.6 & 13.4 & 46.6 & 53.4 & 46.6 \\
\hline \multirow{5}{*}{$\begin{array}{c}L . \\
\text { longiflorus }\end{array}$} & 4.938 & 60 & 40 & 46.6 & 60 & 46.6 \\
\hline & 2.469 & -46.6 & -40 & -40 & -53.4 & -53.4 \\
\hline & 1.235 & -20 & -33.4 & -40 & -40 & -40 \\
\hline & 0.617 & -46.6 & -26.6 & -33.4 & -33.4 & -33.4 \\
\hline & 0.309 & 86.6 & 86.6 & 100 & 93.4 & 86.6 \\
\hline
\end{tabular}

A cytotoxin was reported from L. parasiticus (Zhou et al., 1993). V. roxburghii contains properties to 
show anti-inflammatory activity (Okuda et al., 1987). Except $D$. falcata, other 5 test plants offered strong repellent activity and it is good sign for the investigators working and looking for bioactive potentials in plant resources, since repelling from infestation and deterring from feeding are more acceptable than killing of the pest insects whenever environment friendly protection of crops and stored products is mostly considered.

Table 2. ANOVA results of repellency tests by chloroform extracts of epiphytes against $T$. castaneum adults

\begin{tabular}{|l|c|c|c|c|c|}
\hline & \multicolumn{3}{|l|}{ Sources of variation (df) } & $\begin{array}{c}\text { F-ratio with level of } \\
\text { significance }\end{array}$ \\
\hline $\begin{array}{l}\text { Test } \\
\text { materials }\end{array}$ & $\begin{array}{c}\text { Between } \\
\text { doses }\end{array}$ & $\begin{array}{c}\text { Between } \\
\text { time } \\
\text { interval }\end{array}$ & Error & $\begin{array}{c}\text { Between } \\
\text { doses }\end{array}$ & $\begin{array}{c}\text { Between } \\
\text { time } \\
\text { interval }\end{array}$ \\
\hline D. falcata & 4 & 4 & 16 & $3.267 n s$ & $1.380 \mathrm{~ns}$ \\
\hline C. reflexa & 4 & 4 & 16 & $22.890^{\star \star \star}$ & $0.210 \mathrm{~ns}$ \\
\hline D. roxburghii & 4 & 4 & 16 & $28.961^{\star \star \star}$ & $1.034 \mathrm{~ns}$ \\
\hline F. lacor & 4 & 4 & 16 & $21.752^{\star \star \star}$ & $0.888 \mathrm{~ns}$ \\
\hline V. roxburghii & 4 & 4 & 16 & $37.538^{\star \star \star}$ & $0.186 \mathrm{~ns}$ \\
\hline L. longiflorus & 4 & 4 & 16 & $35.981^{\star \star \star}$ & $1.114 \mathrm{~ns}$ \\
\hline (ns= not significant; $* \star \star$ & $\mathrm{P}<0.001$ & & \\
\hline
\end{tabular}

(ns= not significant; ${ }^{\star \star \star}=\mathrm{P}<0.001$

\section{Acknowledgement}

The authors would like to express grateful thanks to the Bangladesh Council of Scientific and Industrial Research (BCSIR), to the Ministry of Science and Information \& Communication Technology (MOSICT) of Bangladesh for financial support.

\section{References}

Aggarwal, R. \& Dutt, S. 1935. Studies in the chemical constituents of Bombax Ceiba and Cuscuta reflexa. Indigenous drugs of India 2nd eds. U.N. Dhur \& Sons Pvt. Ltd. Calcutta.

Anjaneyulu, A.S.R., Row, L.R., \& Reddy, D.S. 1977. Chemical constituents of Loranthus falcatus Linn. Curr. Sci., 46: 850-851.

Bajracharya, D., Rana, S.J.B. \& Shrestha, A.K. 1978. A general survey and biochemical analysis of fodder plants found in Nagarjun hill forest of Kathmandu valley. J. Nat. Hist. Museum 2: 105-116.

Bhatt, D. 1977. Natural History and Economic Botany of Nepal. Orient Longman Limited. 238 pp.

Bhattarai, S., Subedi, M.N. \& Kurmi, P.P. 2000. Medicinal plant diversity in Tistung and Daman Botanical Garden and surrounding area. In Proceeding of Nepal Japan Joint Symposium on Conservation and Utilization of Himalayan Medicinal Resources - 2000. (T. Watanabe, A., Takano, M.S. Bista \& H.K. Sainju, eds.). pp.189-191. Kathmandu, Nepal.
Chopra, R.N., Nayar, S.L. \& Chopra, I.C. 1956. Glossary of Indian Medicinal Plants. CSIR. Pub., New Delhi, India. 21 pp.

Harvala, E., Exner, J. \& Becker, H. 1984. Flavonoids of Loranthus europaeus. J. Nat. Prod., 47: 1054-1055.

Indrani, N., Rao, V.S., Balasubramanian, K., Reddy, K.K. \& Vijayaramayya, T. 1985. Studies on Loranthus longiflorus Desr. Tannins. Leather Science (Madras), 27: 438-439.

Khan, A. R. \& Selman, B. J. 1981. Some techniques for minimizing the difficulties in egg counting Tribolium castaneum (Herbst). Ent. Rec. Var. 93: 36-37.

Kirtikar, K.R. \& Basu, B.D. 1935. Indian Medicinal Plants. Lalit Mohan Basu Pub. Allahabad (India), 1: 551.

Kusumoto, I.T., Shimada, I., Kakiuchi, N., Hattori, M., Namba, T., \& Supriyatna, S. 1992. Inhibitory effects of Indonesian plant extracts on reverse transcriptase of an RNA tumor virus. (I). Phytother. Res., 6: 241-244.

Lin, J.H. \& Lin, Y.T. 1999. Flavonoids from the leaves of Loranthus kaoi (chao) kiu. Yaowu Shipin Fenxi, 7: 185-190.

Malla, S.B. 1994. Medicinal Herbs in the Bagmati Zone, ADPI- Paper series 8, Kathmandu, ICIMOD. 85pp.

Mallavadhani, U.V., Mahapatra, A., Raja, S.S. \& Manjula, C. 2003. Antifeedant activity of some pentacyclic triterpene acids and their fatty acid ester analogues. J. Agric. Food. Chem. 51 (7): 1952-1955.

Mallavadhani, U.V., Narasimhan, K., Sudhakar, A., Mahapatra, A., Li, W. \& Breemen R. 2006. Three new pentacyclic triterpenes and some flavonoids from the fruits of an Indian Ayurvedic plant Dendrophthoe falcata and their estrogen receptor binding activity. Chem. Pharm. Bull. 54 (5):740-744.

Manandhar, N. P. 1985. Ethnobotanical notes on certain medicinal plants used by Tharus of Dang Deokhuri District, Nepal. Int. J. Crude Drug Res. 23(4): 153-159.

McDonald, L. L., Guy, R. H. \& Speirs, R. D. 1970. Preliminary evaluation of new candidate materials as toxicants, repellents and attractants against storedproduct insects. Agricultural Research Service, U. S. Department of Agriculture, Washington D.C., Marketing Research Report No. 882.a

Nakarmi, M. 2001. Medicinal plant used by Lama community of Ichhangu village in Kathmandu, Central Nepal. Department of Botany, Tribhuvan University, Nepal. 72 pp.

Obatomi, D.K., Aina, V.O., \& Temple, V.J. 1996. Effects of African mistletoe extract on blood pressure in spontaneously hypertensive rats. Int. J. Pharmacog., 34: 124-127. 
Obatomi, D.K., Bikomo, E.O., \& Temple, V.J. 1994. Anti-diabetic properties of the African mistletoe in strptozocin-induced diabetic rats. J. Ethnopharm., 43: 13-17.

Okuda, T., Yoshida, T., Chen, X.M., Xie, J.X. \& Fukushima, M. 1987. Corianin from Coriaria japonica A. Gray and sesquiterpene lactones from Loranthus parasiticus Merr. used for treatment of schizophrenia. Chem. Pharm. Bull. 35: 182-187.

Oli, B. R. 2001. Local knowledge on plant utilization among the major ethnic communities in the eastern Churiya Nepal. Department of Botany, Tribhuvan University, Kathmandu, Nepal. 137 pp.

Pandey, B. 2001. Environmental impacts of Kaligandaki A hydroelectric project on vegetation resource in the dam and reservoir area. Central Department of Botany, Tribhuvan University, Kathmandu, Nepal. $85 \mathrm{pp}$.

Rahman, Atta-ur., Khan, M.A. \& Khan, N.H. 1973. Loranthol. New pentacyclic triterpenoid from Loranthus grewinkii. Phytochem. 12: 3004-3006.

Rai, S.K., Subedi, S. \& Mishra, S. 2004. Utilization pattern of meidicnal plants in Thumpakhar, Sindhupalchok, Nepal. Botanica Orientalis 4: 75-78.
Sadik, G., Islam, R., Rahman, M.M., Khondkar, P., Rashid, M.A. and Sarker, S.D. 2003. Antimicrobial and cytotoxic constituents of Loranthus globosus. Fitoterapia, 74: 308-311.

Talukder, F. A. \& Howse, P. E. 1993. Deterrent and insecticidal effects of extracts of pithraj, Aphanamixis polystachya (Meliaceae), against Tribolium castaueum in storage. J. Chem. Ecol. 19: 2463-2471.

Talukder, F. A. \& Howse, P. E. 1994. Efficacy of pithraj (Aphanamixis polystachya) seed extracts against stored-product pests. Proc. Int. Working Conf. on Stored-prod. Prot. 2: 848-852.

Talukder, F. A. \& Howse, P. E. 1995. Evaluation of Aphanamixis polystachya as a source of repellant, antifeedants, toxicants and protectants in storage against Tribolium castaneum (Herbst), J. Stored. Prod. Res., 31(1): 55-61.

Zhou, H., Zeng, Z., Liu, R., \& Chi, Z. 1993. Purification and characterization of a cytotoxin from Loranthus Parasiticus Merr. Sichuan Daxue Xuebao, 30: 102106.

Zyromska-Rudzka, H. 1966. Abundance and emigration of Tribolium in a laboratory model. Ecol. Pole. A. 14: 491-518. 